GABRIEL, A; RESENDE, JTV; MARODIN, JC; MATOS, R; ZEIST, AR; MACIEL, CDG. 2020. Chemical stress reduces the lateral shoot growth in vernalized garlic. Horticultura Brasileira 38: 41-46. DOI - http://dx.doi.org/10.1590/S0102-053620200106

\title{
Chemical stress reduces the lateral shoot growth in vernalized garlic
}

\author{
André Gabriel ${ }^{1} \mathbb{D}$; Juliano TV Resende ${ }^{2} \mathbb{D}$; Josué C Marodin ${ }^{1} \mathbb{D}$; Rafael de Matos ${ }^{1} \mathbb{D}$; André R Zeist ${ }^{3} \mathbb{D}$; \\ Cleber Daniel G Maciel ${ }^{1} \mathbb{D}$
}

${ }^{1}$ Universidade Estadual do Centro-Oeste (UNICENTRO), Guarapuava-PR, Brasil; andreagrounicentro@gmail.com; josuemarodin@outlook. com; rafamatos@agroconsult.com.br; macielconsultoria@hotmail.com; ${ }^{2}$ Universidade Estadual de Londrina (UEL), Londrina-PR, Brasil; jvresende@uol.com.br; ${ }^{3}$ Universidade do Oeste Paulista (UNOESTE), Presidente Prudente-SP, Brasil; andrezeist@unoeste.br

\begin{abstract}
Brazil's low garlic productivity is attributed, mainly to the lateral shoot growth, a physiological anomaly characterized by early lateral shoot growth of cloves in noble group garlic cultivars. Considering the aforementioned information, the aim was to evaluate the occurrence of lateral shoot growth and productivity characteristics in garlic plants, cv. Chonan, subject to herbicide chemical stress. In order to do so, an experiment was conducted in outlining randomized blocks in a $3 \times 5$ factorial scheme, constituted by three herbicides (paraquat $500 \mathrm{~g} \mathrm{ha}^{-1}$; ammonium gluphosinate $400 \mathrm{~g} \mathrm{ha}^{-1}$ and glyphosate 720 $\left.\mathrm{g} \mathrm{ha}^{-1}\right)$ and five subdoses $(0,5,10,15$ and $20 \%$ of the minimum recommended dose of each herbicide). The electron transport rates (ETR) were evaluated after herbicide application, as well as the culture's morphological and productive characteristics. The chemical stress caused by herbicides paraquat, ammonium gluphosinate and glyphosate in underdoses of 25,40 and 36 i.a. ha ${ }^{-1}$, respectively, was efficient in reducing the electron transport rate and the lateral shoot growth of the Chonan garlic cultivar, and also technically viable in increasing the productivity of commercial bulbs.
\end{abstract}

Keywords: Allium sativum, herbicide, electron transport rate.

\section{RESUMO}

Estresse químico reduz pseudoperfilhamento no alho vernalizado

A baixa produtividade de alho no Brasil é atribuída, principalmente, ao pseudoperfilhamento, anomalia fisiológica caracterizada pela brotação antecipada dos bulbilhos em cultivares de alho do grupo nobre. Considerando as informações supracitadas, objetivou-se avaliar a ocorrência de pseudoperfilhamento e características de produtividade em plantas de alho, cultivar Chonan, submetidas ao estresse químico de herbicidas. Para isso foi conduzido um experimento em delineamento de blocos casualizados com esquema fatorial $3 \times 5$, constituído por três herbicidas (paraquat $500 \mathrm{~g} \mathrm{ha}^{-1}$; amônio glufosinato $400 \mathrm{~g} \mathrm{ha}^{-1}$ e glyphosate $720 \mathrm{~g} \mathrm{ha}^{-1}$ ) e cinco subdoses $(0,5,10,15$ e $20 \%$, da dose mínima recomendada de cada herbicida). Foram avaliadas a taxa de transporte de elétrons (ETR) após a aplicação dos herbicidas, assim como as características morfológicas e produtivas da cultura. O estresse químico dos herbicidas paraquat, amônio glufosinato e glyphosate nas subdoses de 25,40 e 36 i.a. ha ${ }^{-1}$, respectivamente, foi eficiente na redução da taxa de transporte de elétrons e do pseudoperfilhamento da cultivar de alho Chonan, assim como tecnicamente viável no aumento da produtividade de bulbos comerciais.

Palavras-chave: Allium sativum, herbicida, taxa de transporte de elétrons.

\section{Received on December 19, 2018; accepted on September 5, 2019}

$\mathrm{G}$ arlic (Allium sativum) is cultivated in most regions of Brazil, both by large and small producers. In Brazil's South, concentrated production is highlighted in the state of Santa Catarina, where cultivation happens with a greater frequency in small family agriculture properties, with low productivity of commercial standard bulbs.

Lateral shoot growth is one of the factors which causes a decrease in Brazil's garlic productivity. This genetic-physiologically caused anomaly is characterized by the early lateral shoot growth of cloves, which not only reduces the culture productivity, but also depreciates the product, compromising its commercial value (Souza \& Casali, 1986). In this sense, several factors have been related to the lateral shoot growth in garlic, such as photoperiod (Wu et al., 2015, 2016), temperature (Wu et al., 2015, 2016), the cultivar (Resende et al., 2011, 2013; Wu et al., 2016), excessive nitrogen (Marouelli et al., 2002; Trani et al., 2008), irrigation (Marouelli et al., 2002), as well as the regulatory action of gibereline hormones (Vieira et al., 2014; Wu et al., 2016) and jasmonic acid (Wu et al., 2016).
In vernalized noble group garlic cultivars, the lateral shoot growth has been the cause of greatest concern, given they are more sensitive to this anomaly. According to Burba (1983), the vernalization of cloves stimulates the accumulation of citocinines and giberelines, resulting in a change of hormonal balance and premature lateral shoot growth. Therefore, one of the alternatives to reduce the lateral shoot growth, used by Brazilian garlic growers, consists of suspending irrigation during the bulbification period, causing a hydric deficit. The plants' response to 
the hydric deficit is closing its stomata, consequently reducing the diffusion of $\mathrm{CO}_{2}$ to the leaf mesophile, which causes a decrease in photosynthesis (Souza et al., 2001).

The stress in garlic plants induces the production of abscisic acid, which acts as a subdue to giberelines produced during vernalization, in addition to helping the formation of larger bulbs due to the translocation of solutes (Taiz \& Zeiger, 2013).

In Brazil's South, although it possesses the adequate temperature and photoperiod for garlic cultures, rains are frequent during the year and it makes the suspension of irrigation inviable for promoting hydric stress in bulbification. Thus, the excessive humidity increases in this period, resulting in the lateral shoot growth and compromised productivity in commercial garlic bulbs.

In this context, new technology is needed for supplanting in a field level the necessary hydric stress for good culture yield in environments without a defined dry season. In order to achieve this, the application of herbicides acting in specific metabolic routes, diminishing or inhibiting the production of precursor compounds of important molecules for metabolism, such as hormones, chlorophiles, among others (Salmazo, 2009), may, as a means of chemical stress, contribute to the reduction of the lateral shoot growth in garlic. However, there's scarce literature on information about herbicide use aiming to promote chemical stress in vernalized garlic cultivars, in order to minimize the effects of the lateral shoot growth, without affecting the plant significantly.

Therefore, the aim of this research is to promote stress in a garlic culture, through application of herbicide underdoses in the pre-differentiation of cloves, and evaluating its effects on the occurrence of the lateral shoot growth and the commercial yield of bulbs.

\section{MATERIAL AND METHODS}

The experiment was conducted in field on the Olericulture Sector and the Vegetable Phisiology/Horticulture Laboratory of the Agronomy Department, belonging to the Universidade Estadual do Centro-Oeste, in Guarapuava-PR (2523'00's, 51 29'38' W, $1.024 \mathrm{~m}$ altitude). The local climate is classified as humid subtropical mesotermic (Cfb), with mild summers, winters with frost occurrence and frequent rain during the year (without a defined dry season).

The metereological data occurred during the experiment conduction are found in Figure 1, and were obtained in the Instituto Agronômico do Paraná, located $150 \mathrm{~m}$ from the experimental area.

The experimental outlining used was randomized blocks, with fifteen treatments and four repetitions. The treatments were represented by factorial $3 \times 5$, where three herbicides were used (paraquat $500 \mathrm{~g} \mathrm{ha}^{-1}$; ammonium gluphosinate $400 \mathrm{~g} \mathrm{ha}^{-1}$ and glyphosate $\left.720 \mathrm{~g} \mathrm{ha}^{-1}\right)$ and five underdoses $(0$, $5,10,15$ and $20 \%$ of the minimum recommended dose of each herbicide).

The planting of the cloves was made in May 25, 2016, using patches $1 \mathrm{~m}$ width and $0.2 \mathrm{~m}$ height, $0.3 \mathrm{~m}$ space between lines and $0.10 \mathrm{~m}$ between plants, the final population being 333,000 plants $\mathrm{ha}^{-1}$. The experimental units were composed of $3.6 \mathrm{~m}^{2}$ divisions, with three simple lines $4 \mathrm{~m}$ long garlic plants, totalizing 120 plants. The area considered to be useful was 30 plants in the central lines.

The noble group cultivar Chonan was used, which presents high susceptibility to the lateral shoot growth. The used bulbs were class 5 (transversal diameter between 42 and $47 \mathrm{~mm}$ ) and cloves with an average mass between 2.7-3.3 $\mathrm{g} /$ clove. The cloves were stored in a cold chamber at $4^{\circ} \mathrm{C}$ and $75 \%$ moisture, during 20 days for the vernalization process.

The plantation's fertilization was performed in accordance to the soil's chemical analysis results, with the application of $100 \mathrm{~kg} \mathrm{ha}^{-1}$ of simple superphosphate. $\left(20 \% \mathrm{P}_{2} \mathrm{O}_{5}\right.$ and $\left.12 \% \mathrm{~S}\right)$ and $500 \mathrm{~kg} \mathrm{ha}^{-1}$ of 04-14-08 formulation (NPK). In the fertilization, performed 50 days after planting, $50 \mathrm{~kg}$ of $\mathrm{N} \mathrm{ha}^{-1}$ were used $(46 \% \mathrm{~N})$.

Weeds were manually handled whenever necessary, so that the culture would remain unaffected by interference. Pests and diseases were controlled daily monitoring the experimental area with application of fungicides and insecticides registered in accordance to the culture's needs, in accordance to technical recommendations (Pavan \& Sakate, 2014). Approximately 100 days after planting started the differentiation phase, characterized by the occurrence of cloves in early formation at the stems' base. The chemical stress was inducted 105 days after planting with application of herbicides, with the purpose of reducing the lateral shoot growth on the plants.

For the application of the herbicides, a $\mathrm{CO}_{2}$ pressurized coastal pulverizer equipped with a model AD 110.015 twotipped bar, with $0,5 \mathrm{~m}$ space between them and $0.5 \mathrm{~m}$ from the plants, in a $3.6 \mathrm{~km} \mathrm{~h}^{-1}$ movement speed was used. This application constituted a $150 \mathrm{~L} \mathrm{ha}^{-1}$ rate. In the moment of this application, performed between $10 \mathrm{~h} 00 \mathrm{~min}$ and $11 \mathrm{~h} 00 \mathrm{~min}$, climate conditions were monitored with a portable digital termoanemometer. The temperature, relative air moisture and wind speed were $25^{\circ} \mathrm{C}$, $65 \%$ and $2 \mathrm{~km} \mathrm{~h}^{-1}$, respectively.

At 7 and 14 days after the herbicide application (DAA) the electron transport rate was evaluated $\left(\mathrm{ETR}=\mu \mathrm{mol} \mathrm{m} \mathrm{m}^{-2}\right.$ $\mathrm{s}^{-1)}$ in garlic plants, using a portable fluorometer, model Y(II) Meter, from Opti-Science ${ }^{\circledR}$.

Plants were harvested 180 days after planting, when they showed signs of ripening characterized by yellowing and drying $2 / 3$ of the aerial part. In this period evaluations were made of the plants' height $(\mathrm{PH}, \mathrm{cm})$, number of leaves (NL) and pseudo stem diameter (PD, mm). Plants were harvested manually, being subjected to a precuring process, remaining exposed for three days to the sun in such a way that the leaves of one plant would cover the bulbs of the other, shielding it from solar radiation. Afterwards the curing was performed, in which the plants remained for a 35-day period in dry and aerated area.

After the curing process, bulbs were cleaned and evaluations made of total bulb productivity (TBP in $\mathrm{t} \mathrm{ha}^{-1}$ ), bulbs 
with the lateral shoot growth LSG (\%) and commercial bulb productivity (CBP, in $\mathrm{tha}^{-1}$ ).

After verifying the normality and homogeneity of variances through the Shapiro-Wilk and Bartlett tests, respectively, the data were subjected to the Sisvar ${ }^{\circledR}$ statistic software and the variance analysis performed. Averages were compared by the Scott-Knott grouping test $(\mathrm{p} \leq 0.05)$. In addition, all characteristics were subjected to regression analysis, with the polynomial square model.

\section{RESULTS AND DISCUSSION}

The application of paraquat, ammonium gluphosinate and glyphosate at $5 \%$ of the commercial dose, respectively represented by 25 , 20 and $36 \mathrm{~g} \mathrm{ha}^{-1}$, reducing the electron transport rate (ETR) in the Chonan garlic cultivar plants, indicating that chemical stress was in general more expressive at 7 days if compared to 14 DAA (Figure 2). In addition, the garlic cultivar Chonan presented a very similar behavior in relation to ETR reduction, when subjected to the three herbicide underdoses in the beginning of the cloves' differentiation, although possessing different mechanisms and behaviors (Roman et al., 2007).

It is important to highlight that herbicide underdoses cause chemical stress in the cloves' differentiation period, inducing the formation of

Table 1. Plant height (PH), number of leaves (NL), pseudo stem diameter (PD), total bulb productivity (TBP), lateral shoot growth (LSG), commercial bulb productivity (CBP) and regression equation. Guarapuava, UNICENTRO, 2018.

\begin{tabular}{|c|c|c|c|c|c|c|c|c|}
\hline \multirow{2}{*}{ Herbicides } & \multicolumn{5}{|c|}{ Herbicide dose (\%) } & \multirow{2}{*}{ Mean } & \multirow{2}{*}{ Regression equation } & \multirow{2}{*}{$\mathbf{R}^{2}$} \\
\hline & $\mathbf{0}$ & 5 & 10 & 15 & 20 & & & \\
\hline \multicolumn{9}{|c|}{ PH (cm) } \\
\hline Paraquat & $84.05 \mathrm{aA}$ & $77.77 \mathrm{bB}$ & $73.87 \mathrm{bC}$ & $73.02 \mathrm{bC}$ & $71.77 \mathrm{bC}$ & $76.10 \mathrm{~b}$ & $0.0375 x^{2}-1.3353 x+83.831$ & 0.98 \\
\hline Ammonium gluphosinate & $84.05 \mathrm{aA}$ & $82.65 \mathrm{aA}$ & $82.52 \mathrm{aA}$ & $81.17 \mathrm{aA}$ & $79.55 \mathrm{aA}$ & $81.99 \mathrm{a}$ & $-0.0047 x^{2}-0.1147 x+83.847$ & 0.96 \\
\hline Glyphosate & $84.05 \mathrm{aA}$ & $82.75 \mathrm{aA}$ & $81.25 \mathrm{aA}$ & $80.80 \mathrm{aA}$ & $79.15 \mathrm{aA}$ & $81.60 \mathrm{a}$ & $0.0010 x^{2}-0.2550 x+84.000$ & 0.98 \\
\hline \multirow[t]{2}{*}{ Mean } & $84.05 \mathrm{~A}$ & $81.05 \mathrm{~B}$ & $79.21 \mathrm{C}$ & $78.33 \mathrm{C}$ & $76.82 \mathrm{C}$ & & & \\
\hline & & & NL & & & & & \\
\hline Paraquat & $7.95 \mathrm{aA}$ & $7.25 \mathrm{aB}$ & $6.92 \mathrm{aB}$ & $6.85 \mathrm{aB}$ & $6.82 \mathrm{aB}$ & $7.16 \mathrm{~b}$ & $0.0046 x^{2}-0.1446 x+7.9186$ & 0.98 \\
\hline Ammonium gluphosinate & $7.95 \mathrm{aA}$ & $7.30 \mathrm{aB}$ & $7.22 \mathrm{aB}$ & $7.02 \mathrm{aB}$ & $7.05 \mathrm{aB}$ & $7.31 \mathrm{~b}$ & $0.0035 x^{2}-0.1125 x+7.9011$ & 0.95 \\
\hline Glyphosate & $7.95 \mathrm{aA}$ & $7.87 \mathrm{aA}$ & $7.60 \mathrm{aA}$ & $7.55 \mathrm{aA}$ & $7.07 \mathrm{aA}$ & $7.61 \mathrm{a}$ & $-0.0017 x^{2}-0.0085 x+7.9411$ & 0.95 \\
\hline \multirow[t]{2}{*}{ Mean } & $7.95 \mathrm{~A}$ & $7.47 \mathrm{~B}$ & $7.25 \mathrm{~B}$ & $7.14 \mathrm{~B}$ & $6.98 \mathrm{~B}$ & & & \\
\hline & \multicolumn{5}{|c|}{ PD (mm) } & & & \\
\hline Paraquat & $16.62 \mathrm{aA}$ & $14.06 \mathrm{aB}$ & $13.96 \mathrm{aB}$ & $13.63 \mathrm{aB}$ & $13.69 \mathrm{aB}$ & $14.39 \mathrm{a}$ & $0.0143 x^{2}-0.4121 x+16.366$ & 0.90 \\
\hline Ammonium gluphosinate & $16.62 \mathrm{aA}$ & $14.61 \mathrm{aB}$ & $14.54 \mathrm{aB}$ & $14.19 \mathrm{aB}$ & $13.84 \mathrm{aB}$ & $14.76 \mathrm{a}$ & $0.0087 x^{2}-0.2933 x+16.390$ & 0.90 \\
\hline Glyphosate & $16.62 \mathrm{aA}$ & $14.91 \mathrm{aA}$ & $14.75 \mathrm{aA}$ & $14.13 \mathrm{aA}$ & $13.55 \mathrm{aA}$ & $14.79 \mathrm{a}$ & $0.0051 x^{2}-0.2413 x+16.433$ & 0.94 \\
\hline \multirow[t]{2}{*}{ Mean } & $16.62 \mathrm{~A}$ & $14.53 \mathrm{~B}$ & $14.42 \mathrm{~B}$ & $13.98 \mathrm{~B}$ & $13.69 \mathrm{~B}$ & & & \\
\hline & \multicolumn{5}{|c|}{$\operatorname{TBP}\left(\mathrm{t} \mathrm{ha}^{-1}\right)$} & & & \\
\hline Paraquat & $16.61 \mathrm{aA}$ & $13.91 \mathrm{aB}$ & $13.52 \mathrm{aB}$ & $13.07 \mathrm{aB}$ & $12.63 \mathrm{aB}$ & $13.95 \mathrm{~b}$ & $-0.0009 x^{2}-0.1969 x+16.814$ & 0.94 \\
\hline Ammonium gluphosinate & $16.61 \mathrm{aA}$ & $15.52 \mathrm{aA}$ & $16.05 \mathrm{aA}$ & $14.24 \mathrm{aB}$ & $13.88 \mathrm{aB}$ & $14.71 \mathrm{a}$ & $0.0127 x^{2}-0.4309 x+16.334$ & 0.93 \\
\hline Glyphosate & $16.61 \mathrm{aA}$ & $16.39 \mathrm{aA}$ & $14.23 \mathrm{aB}$ & $13.77 \mathrm{aB}$ & $12.54 \mathrm{aB}$ & $15.26 \mathrm{a}$ & $-0.0025 x^{2}-0.0845 x+16.482$ & 0.84 \\
\hline \multirow[t]{2}{*}{ Mean } & $16.61 \mathrm{~A}$ & $15.27 \mathrm{~B}$ & $14.60 \mathrm{C}$ & $13.70 \mathrm{C}$ & $13.01 \mathrm{C}$ & & & \\
\hline & \multicolumn{5}{|c|}{ LSG (\%) } & & & \\
\hline Paraquat & $63.35 \mathrm{aA}$ & $25.12 \mathrm{bB}$ & $42.03 \mathrm{aA}$ & $47.77 \mathrm{aA}$ & $51.76 \mathrm{aA}$ & $46.00 \mathrm{~b}$ & $0.2093 x^{2}-4.1975 x+56.579$ & 0.48 \\
\hline Ammonium gluphosinate & $63.35 \mathrm{aA}$ & $39.06 \mathrm{aB}$ & $33.16 \mathrm{aB}$ & $44.36 \mathrm{aB}$ & $45.08 \mathrm{aB}$ & $45.00 \mathrm{~b}$ & $0.1918 x^{2}-4.4602 x+60.839$ & 0.81 \\
\hline Glyphosate & $63.35 \mathrm{aA}$ & $43.55 \mathrm{aA}$ & $51.75 \mathrm{aA}$ & $53.27 \mathrm{aA}$ & $62.06 \mathrm{aA}$ & $54.80 \mathrm{a}$ & $0.1443 x^{2}-2.7429 x+60.582$ & 0.70 \\
\hline \multirow[t]{2}{*}{ Mean } & $63.35 \mathrm{~A}$ & $35.91 \mathrm{D}$ & $42.31 \mathrm{C}$ & $48.47 \mathrm{C}$ & $52.96 \mathrm{~B}$ & & & \\
\hline & \multicolumn{5}{|c|}{$\operatorname{CBP}\left(\mathrm{t} \mathrm{ha}^{-1}\right)$} & & & \\
\hline Paraquat & $6.01 \mathrm{aB}$ & $10.23 \mathrm{aA}$ & $7.57 \mathrm{bB}$ & $6.83 \mathrm{aB}$ & $6.12 \mathrm{bB}$ & $7.35 \mathrm{~b}$ & $-0.0227 x^{2}+0.3901 x+6.8537$ & 0.46 \\
\hline Ammonium gluphosinate & $6.01 \mathrm{aB}$ & $9.48 \mathrm{aA}$ & $10.75 \mathrm{aA}$ & $7.82 \mathrm{aB}$ & $7.66 \mathrm{aB}$ & $8.34 \mathrm{a}$ & $-0.0327 x^{2}+0.6877 x+6.3789$ & 0.72 \\
\hline Glyphosate & $6.01 \mathrm{aB}$ & $9.17 \mathrm{aA}$ & $6.86 \mathrm{bB}$ & $6.43 \mathrm{aB}$ & $4.60 \mathrm{bB}$ & $6.61 \mathrm{~b}$ & $-0.0231 x^{2}+0.3517 x+6.5689$ & 0.70 \\
\hline Mean & $6.01 \mathrm{C}$ & $9.62 \mathrm{~A}$ & $8.39 \mathrm{~B}$ & $7.03 \mathrm{C}$ & $6.12 \mathrm{C}$ & & & \\
\hline
\end{tabular}

*Means followed by same lowercase letters in the column and uppercase letters in the row belong to the same group by the Scott-Knott test, $\mathrm{p} \leq 0.05$. 
abscisic acid, responsible for solute translocation, opening and closing of stomata and antagonizing the giberelines (Taiz \& Zeiger, 2013). During the garlic vernalization period the gibereline synthesis is related to clove differentiation and promotion of the lateral shoot growth in the culture (Vieira et al., 2014).

Evaluations of ETR in chemical handling of weeds are frequently used in many cultures to indicate the susceptibility of some herbicides, such as photosynthesis inhibitors, in quantifying the interference degree on plants (Baker 2008; Dayan \& Zaccaro, 2012; Girotto et al., 2012; Tropaldi et al., 2015). It should be remarked that, due to what is proposed in this work, the interference of chemical stress in garlic plants should not be so intense to reduce productivity and the bulbs' commercial quality. In this way, fluorescence is used as a non-destructive technique, capable of obtaining abiotic stress results caused by herbicides in a rapid diagnosis after application (Korres et al., 2003).

In the data analysis, no significant interactions were found between herbicide $\mathrm{x}$ underdose for the evaluated characteristics in the garlic culture. However, considering the variation factors in an isolated manner, there was no significant difference of the herbicide doses for pseudostem diameter (PD), lateral shoot growth (LSG) and total bulb productivity (TBP). Considering the underdose factor, no significant differences were observed only for $\mathrm{PH}$ with ammonium gluphosinate, as well as for PH, NL, PD, and LSG with glyphosate (Table 1).

Generally, the herbicide underdoses affected negatively the production components of Chonan vernalized garlic cultivar and promoted chemical stress with decrease in lateral shoot growth (Table 1). This factor can be verified in witness without herbicide application (dose $0 \%$ ), in which a higher PH, NL, PD, TBP and LSG, and a smaller commercial bulb productivity (CBP) was observed. In this context, the main highlight among herbicides occurred for paraquat in a $5 \%$ underdose causing a PH, NL, PD, TBP and LSG decrease, and a $58.74 \%$ increase in CBP.

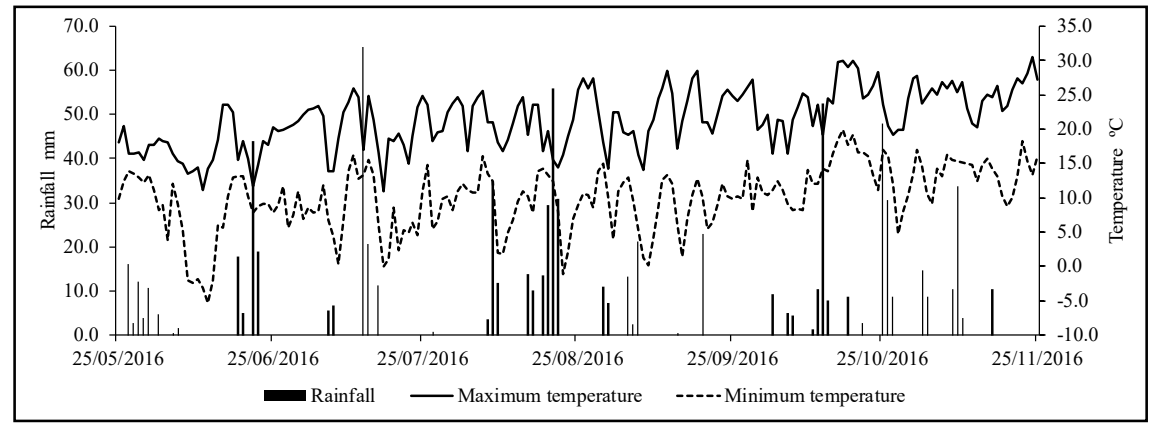

Figure 1. Daily weather data of maximum and minimum temperatures $\left({ }^{\circ} \mathrm{C}\right)$ and of rainfall $(\mathrm{mm})$ occured during the period of conduction of the experiment. Guarapuava, UNICENTRO, 2018.
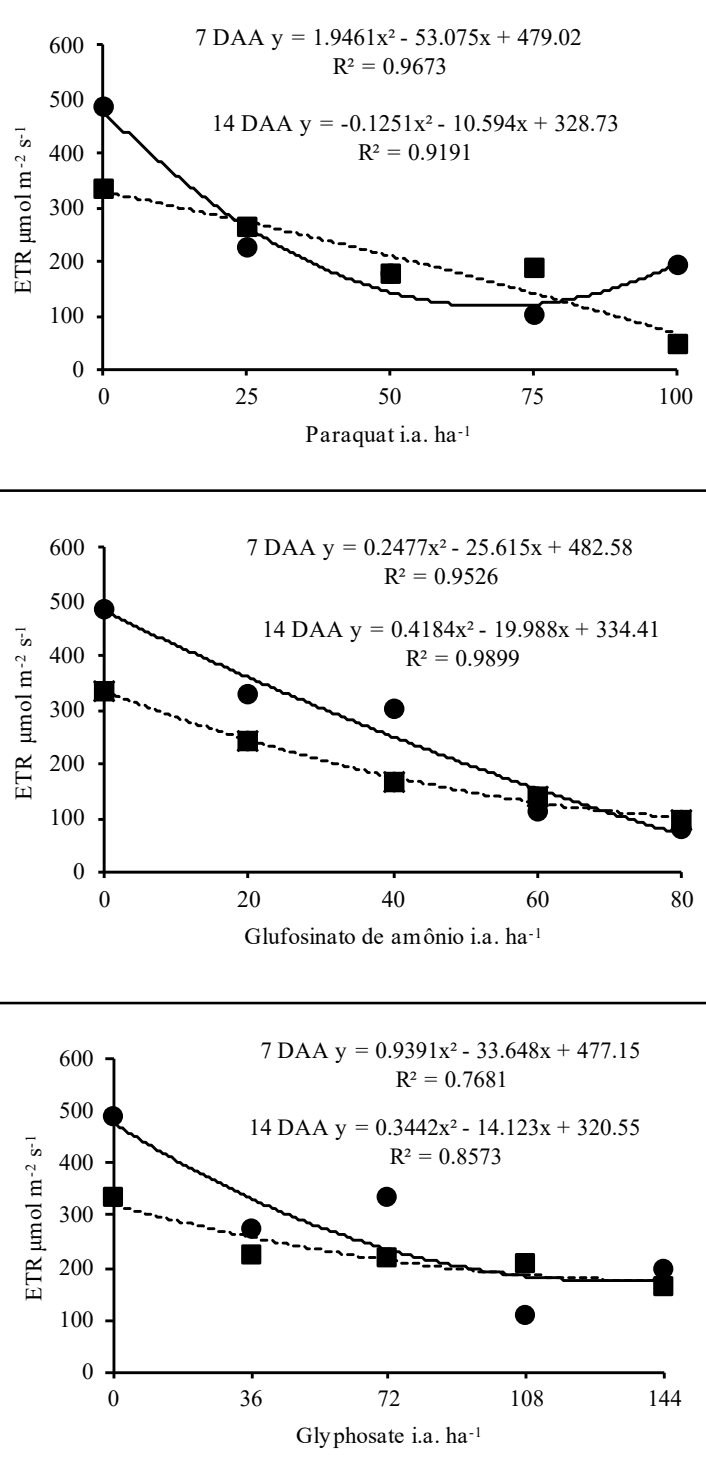

$$
\text { - } 7 \text { Days after application (7 DAA) }
$$

- 14 Days after application (14 DAA)

Figure 2. Electron transport rate (ETR) in the Chonan garlic cultivar at 7 and 14 days after application (DAA) of the paraquat, ammonium gluphosinate and glyphosate herbicides. Guarapuava, UNICENTRO, 2018. 
This herbicide presents contact action with fast leaf absorption and limited translocation, as well as an electron flux blocking mechanism in the photosystem I (PSI) transport chain, which can, in few hours, cause phytotoxic effects on plants directly exposed to sunlight (Roman et al., 2007; Oliveira Junior, 2011; Larotte et al., 2015).

Concerning $\mathrm{PH}$, no differences among ammonium gluphosynate and glyphosate occurred when compared to the witness (no application). Contrarily, paraquat has negatively affected this characteristic, from an application of 5\% of the commercial dose $\left(25 \mathrm{~g} \mathrm{ha}^{-1}\right)$ (Table 1). For NL, no significant difference occurred among the herbicides, and only difference for paraquat and ammonium gluphosynate doses, concerning the witness without application (Table 1). From 5\% of paraquat and ammonium gluphosynate, chemical stress was evidenced by the reduction of the garlic plant's NL.

The fact of the $\mathrm{PH}$ and NL variables not having been influenced by glyphosate might be attributed by the characteristics of the studied species and dose, as well as of the herbicide's mechanism of action, since it may take from two to four weeks to cause phytotoxic effects on the plants (Rodrigues \& Almeida, 2011). Glyphosate acts inhibiting the action of enzyme enol piruvil shikimate phosphate synthase (ESPSs), paralyzing the synthesis of amino acids phenylalanine, tyrosine and tryptophan, and secondary compounds such as alcaloids, cumarines and flavonoids, in addition to inhibiting the production of chlorophiles and stimulating the production of ethylene and ascetic indol acid (AIA) (Kruse et al., 2000; Galli \& Montezuma, 2005; Roman et al., 2007).

Similar results were observed for the pseudostem diameter (PD), in NL (Table 1). Resende et al. (2013) found in Guarapuava-PR that noble group garlic cultivars presented a larger pseudostem diameter, total bulb production and percentage of bulbs with lateral shoot growth and even so there was no difference concerning the productivity of commercial bulbs of the seminoble group garlic cultivars. According to the authors, a genetic variability between the genotypes of the noble group garlic to those with lateral shoot growth varied between $16.2 \%$ (São Valentim cultivar) to $99.2 \%$ (Bergamota cultivar).

In total bulb productivity (TBP), no difference was found for the herbicide, but in average a $17.62 \%$ was found for a higher herbicide dose (20\%), in relation to the witness without application. There was a TBP reduction of 5, 15 and $10 \%$ doses for paraquat, ammonium gluphosynate and glyphosate, respectively; the behavior found in the underdose-response description adjusted with high precision $\left(\mathrm{R}^{2} \geq\right.$ $0.84)$ to the polynomial square model (Table 1). However, lower losses were remarked by the formation of abnormal bulbs with lateral shoot growth LSG from underdoses of 5\% paraquat and ammonium gluphosynate, instead of glyphosate, which did not show the same behavior (Table 1). For this variable, the adjustment to the polynomial square model with glyphosate was superior to that of paraquat $\left(R^{2} \geq 0.48\right)$ and inferior to ammonium gluphosynate $\left(\mathrm{R}^{2} \geq 0.81\right)$.

A higher productivity was remarked for commercial bulbs (CBP), the $5 \%$ underdoses of paraquat and glyphosate, along with $10 \%$ for ammonium gluphosynate, which resulted in enhancement in relation to the control, around $41.25 ; 44.09$ and $34.46 \%$, respectively. Research results with stimulating effects of herbicide underdoses for a desirable phenotypical change, although still restricted in garlic cultures, have already been investigated for a large variety of cultures, and this phenomenon has been named "hormesis" or "hermetic effect" (Duke et al., 2006). Velini et al. (2008) reported a stimulus of a glyphosate underdose to the growth of five species of plants and an absence of this effect to plants resistant to glyphosate ( $R R$ soy), showing that hormesis may be probably related to the site of action of the aforementioned herbicide.

Lateral shoot growth is considered a phyisiological genetic anomaly that may cause the garlic culture to produce defective bulbs (Resende et al., 2017). The importance of new research geared towards the selection of genotypes better-adapted to the edaphoclimatic conditions of the Center-South region of the state of Paraná, in addition to promising handling techniques, such as chemical stress induced by herbicides, becomes clearer than ever. In this sense, we also highlight that the investigation of the use of herbicides to reduce lateral shoot growth, will be necessary to know the minimum period of latency between application and harvest of the garlic culture, in a way that the Maximum Residual Limit (MRL) is safely below the levels established by Brazil's regulatory agencies, such as ANVISA [Agência Nacional de Vigilância Sanitária (National Sanitary Inspection Agency)].

The chemical stress of herbicides paraquat, ammonium gluphosynate and glyphosate in the 25,40 and 26 i.a. ha $^{-1}$ underdoses, respectively, was efficient in reducing the electron transport rate and lateral shoot growth of the vernalized Chonan garlic culture, as well as technically viable in increasing the productivity of the Chonan garlic cultivar commercial bulbs.

\section{REFERENCES}

BAKER, NR. 2008. Chlorophyll fluorescence: a probe of photosynthesis in vivo. Annual Review of Plant Biology 59: 89-113.

BURBA, JL. 1983. Efeitos do manejo de alho-semente (Allium sativum L.) sobre a dormencia, crescimento e produção da cultivar Chonan. Viçosa: UFV. 112p (M.Sc. thesis).

DAYAN, FE; ZACCARO, MLM. 2012. Chlorophyll fluorescence as a marker for herbicide mechanisms of action. Pesticide Biochemistry and Physiology 102: 189-197.

DUKE, SO; CEDERGREEN, N; VELINI, ED; BELZ, R. 2006. Hormesis: is it an important factor in herbicide use and allelopathy?. New York: Outlooks on Pest Management, p.29-33.

GALLI, AJB.; MONTEZUMA, MC. 2005. Glifosato: alguns aspectos da utilização do herbicida glifosato na agricultura. São Paulo: Acadcom.

GIROTTO, M; ARALDI, R; VELINI, ED; TRINDADE, MLB; CARBONARI, CA. 2012. Efeito do hexazinone isolado e em mistura na eficiência fotossintética de Panicum maximum. Planta Daninha 30: 341-347.

KORRES, NE; FROUD-WILLIAMS, RJ; MOSS, SR. 2003. Chlorophyll fluorescence technique as a rapid diagnostic test of the effects of the photosynthetic inhibitor chlorotoluron on two winter wheat cultivars. Annals of Applied Biology 143: 53-56.

KRUSE, ND; TREZZI, MM; VIDAL, RA. 2000. Herbicidas inibidores da EPSPs: Revisão de 
Literatura. Revista Brasileira de Herbicidas, 1: 139-146.

LAROTTE, DO; MATOS, AKA; MACEDO, GC. 2015. Modo de ação dos herbicidas. In: BALDIN, ELL; KRONKA, AZ; FUJIHARA, RT. Proteção Vegetal p.138-160.

MAROUELLI, WA; SILVA, WLC; CARRIJO, OA; SILVA, HR. 2002. Produção e qualidade de alho sob regimes de água no solo e doses de nitrogênio. Horticultura Brasileira 20: 191-194.

OLIVEIRA JUNIOR, RS. 2011. Mecanismo de ação de herbicidas. In: OLIVEIRA JUNIOR, RS; CONSTANTIN, J; INOUE, MH. Biologia e manejo de plantas daninhas. Curitiba: Omnipax Editora. p.243-262.

PAVAN, MA; SAKATE, RK. 2014. A cultura do alho: produzir com qualidade para competir. 1.ed. Pompeia: Fundação Shunji Nishimura de Tecnologia. 203p.

RESENDE, JTV; MORALES, RGF; RESENDE, FV; FARIA, MV; SOUZA, RJ; MARCHESE, A. 2011. Garlic vernalization and planting dates in Guarapuava. Horticultura Brasileira 29: 193-198.

RESENDE, JTV; MORALES, RGF; ZANIN, DS; RESENDE, FV; PAULA, JT; DIAS, DM; GALVÃO, AG. 2013. Caracterização morfológica, produtividade e rendimento comercial de cultivares de alho. Horticultura
Brasileira 31: 157-162.

RESENDE, FV; NASSUR, RCMR; HABER, LL. 2017. Cultivares recomendados. In: NICK, C; BORÉM, A. Alho: do plantio a colheita. Viçosa: Editora UFV. p.67-90.

RODRIGUES, BN; ALMEIDA, FS. 2011. Guia de Herbicidas. 6.ed. Londrina: 697p.

ROMAN, ES; BERCKIE, H; VARGAS, L; HALL, L; RIZZARDI, MA; WOLF, TM. 2007. Como funcionam os herbicidas: da biologia à aplicação. 1. ed. Passo Fundo: Editora Berthier. 160p.

SALMAZO, PB. 2009. Efeitos de subdoses de sulfoniluréias na produtividade e qualidade de tubérculos de batata (Solanum tuberosum L.). Piracicaba: USP-ESALQ. 93p (M.Sc. thesis).

SOUZA, RJ; CASALI, VWD. 1986. Pseudoperfilhamento - uma anormalidade genético-fisiológica em alho. Informe Agropecuário 12: 36-41.

SOUZA, CR; SOARES, AM; REGINA, MA. 2001. Trocas gasosas de mudas de videira, obtidas por dois porta-enxertos, submetidas à deficiência hídrica. Pesquisa Agropecuária Brasileira 36: 1221-1230.

TAIZ, L; ZEIGER, E. 2013. Fisiologia vegetal. 5.ed. Porto Alegre 918p.

TRANI, PE; CAMARGO, MS; FOLTRAN, DE; HIROCE, R;ARRUDA, FB; SAWAZAKI, HE.
2008. Produtividade e pseudoperfilhamento do alho influenciados pelo nitrogênio, potássio e cobertura morta. Horticultura Brasileira 26: 330-334.

TROPALDI, L; VELINI, ED; CARBONARI, CA; ARALDI, R; CORNIANI, N; GIROTTO, M; SILVA, IPF. 2015. Detecção da tolerância de diferentes espécies de capim-colchão a herbicidas inibidores do fotossistema II utilizando a técnica da fluorescência. Ciência Rural 45: 767-773.

VELINI, ED; ALVES, E; GODOY, MC; MESCHEDE, DK; SOUZA, RT; DUKE, SO. 2008. Glyphosate applied at low doses can stimulate plant growth. Pesticide Management Science 64: 489-496.

VIEIRA, RL; SILVA, AL; ZAFFARI, GR; FELTRIM, AL. 2014. Morfogênese de plantas de alho in vitro: papel dos reguladores de crescimento na indução e desenvolvimento de bulbos. Ciência Rural 44: 439-445.

WU, C; WANG, M; DONG, Y; CHENG, Z; MENG, H. 2015. Growth, bolting and yield of garlic (Allium sativum L.) in response to clove chilling treatment. Scientia Horticulturae 194: 43-52.

WU, C; WANG, M; CHENG, Z; MENG, H. 2016. Response of garlic (Allium sativum L.) bolting and bulbing to temperature and photoperiod treatments. Biology Open 5: 507-518. 